\title{
Quantitative Analysis of Gene Expression in Different Tissues by Template-calibrated RT-PCR and Laser-induced Fluorescence
}

\author{
Wolfram J.P. Karges, Roger Gaedigk, and H.-Michael Dosch \\ Department of Pediatrics and Immunology, The Hospital for Sick Children, Toronto M8X 1G5, Canada
}

\begin{abstract}
RT-PCR is widely used to study gene transcription in many biological systems. Despite the development of a variety of, at times complex, procedures, quantitation of RT-PCR remains difficult, particularly when comparing RNA from different tissues or very small samples. In the procedure described here, we calibrate input CDNA through incorporation of trace label. PCR product is generated from equal amounts of cDNA with fluoresceinated primers, size fractionated, and quantitated by laser-induced fluorescence in an automated DNA sequencer. Eliminating variation in input CDNA resulted in reliable noncompetitive PCR quantitation from templates equivalent to $\$ 50 \mathrm{pg}$ of total RNA. Using the example of $\beta$-glucuronidase, a low-copynumber housekeeping gene, we have drawn a map of differential gene expression for this protein in various rat tissues.
\end{abstract}

D Neverse transcriptase-PCR (RT-PCR) has enabled important experiments dealing with gene expression and its regulation. More sensitive and less laborious than Northern blot hybridization and RNase protection assays, it has rapidly become a common procedure. ${ }^{(1)}$ However, quantitation of gene expression by RT-PCR is hampered by stochastic variation of PCR amplification efficiency. In addition, owing to variable efficiency and quality of RNA isolation and reverse transcription, the amount of input cDNA is a major source of variation in quantitative RT-PCR. Several procedures address these problems through endogenous or exogenous, internal or external standards or primer/template competition (for review, see Ref. 2). Quantitation of PCR products by isotope incorporation during PCR or Southern blot hybridization using radioactive probes is inconvenient, and most scanning systems provide only a narrow range of linear detection.

These difficulties are emphasized in applications that rely on very small biological samples where RNA cannot be efficiently extracted and quantitated by standard means or when samples from different tissue sources are compared where RNA isolation efficiency, quality, and optical quantitation vary.

We encountered these problems after cloning a novel, diabetes-associated gene, p69(ICA1), ${ }^{(3,4)}$ and wished to establish its expression in different tissues and species. ${ }^{(5)}$ To obtain sufficient (measurable) quantities and qualities of RNA from different, often small, tissue samples, was challenging, for example, mouse neuroendocrine tissue. We therefore looked for a different approach to calibrate PCR template input and to quantitate amplification in a linear detection system that allowed comparisons over a range of several orders of magnitude. Our strategy is relatively simple: By calibrating input cDNA through trace labeling of the reverse transcriptase reaction and by using fluorescent primers and an automated sequencer for PCR product quantitation, we were able to characterize and confirm this quantitative PCR system, which provides good reproducibility, linearity, and practicality.

\section{MATERIALS AND METHODS}

\section{RNA Isolation}

Fresh tissue ( $\sim 1-50 \mathrm{mg}$ ) from healthy 8to 14 -week-old Wistar rats was snap-frozen in liquid nitrogen, ground to powder at $-100^{\circ} \mathrm{C}$, and quickly transferred to lysis buffer. Pancreatic islets, isolated by standard collagenase preparation, or NIT cells (kind gift of Dr. B. Singh, University of Western Ontario, London, Ontario) from a mouse islet cell line were directly resuspended in lysis buffer. ${ }^{(6)}$ Total RNA was then extracted using a standard acid guanidinium thiocyanate-phenol method. ${ }^{(7)}$ Quantities allowing, RNA was measured spectrophotometrically and integrity was estimated on an EtBrstained agarose gel.

\section{CDNA Synthesis and Calibration}

cDNA was synthesized from $\sim 3 \mu \mathrm{g}$ of total RNA using $1 \mu \mathrm{g}$ of oligo(dT) ${ }_{12-18}$ (Pharmacia) and 200 units of Moloney murine leukemia virus (Mo-MLV) reverse transcriptase (GIBCO BRL, Mississauga, Ontario) as recommended by the manufacturer. The amount of cDNA 


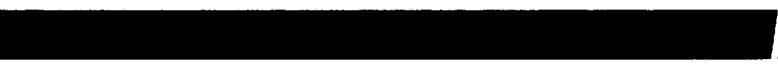

template generated was measured by incorporation of labeled dCTP. In each experiment, two parallel $40-\mu \mathrm{l}$ reactions were performed per sample, either in the presence or absence of $10 \mu \mathrm{Ci}$ of $\left[\alpha-{ }^{32}\right.$ P]dCTP (Fig. 1). Unincorporated nucleotides were removed on a Sephacryl spin column (MicroSpin S-200HR, Pharmacia). The specific activity of each cDNA sample was determined by scintillation counting, and incorporation data were used to ascertain that equal amounts of cDNA template were used in the subsequent PCR amplification. To allow direct comparisons between different experiments (e.g., when using isotope of different specific activity or different batches of reverse transcriptase), a standard RNA was isolated in a large batch from a convenient source (in our case, NIT islet cell line) and kept frozen in aliquots at $-80^{\circ} \mathrm{C}$. One aliquot was included in each cDNA synthesis series as a standard. The cDNA generated from this identical RNA was used as a standard $(100 \%)$, with which all other cDNAs were compared (see Fig. 3, below, for illustration). Only nonradioactive cDNA was used for PCR amplification.

\section{PCR}

To the PCR master mixture $[10 \mathrm{~mm}$ Tris$\mathrm{HCl}$ (pH 9.0), $50 \mathrm{~mm} \mathrm{KCl}, 1.5 \mathrm{~mm} \mathrm{MgCl}_{2}$, $\mathrm{dNTP} \operatorname{mix}(200 \mu \mathrm{M}$ each), $50 \mathrm{ng}$ of each primer, 2.5 units of Taq DNA polymerase (Pharmacia)] we added calibrated cDNA (0.4-2.5 $\mu$ l, depending on results above) to a final volume of $50 \mu \mathrm{l}$. $\beta$-Glucuronidase primers ( $\beta$-Glu-S, $5^{\prime}$-GTGATGTGGTCTGTGGCCAA- ${ }^{\prime}$, and $\beta$-Glu-AS, $5^{\prime}$-TCTGCTCCATACTCGCTCTG-3'), ${ }^{\left({ }^{(8)}\right.}$

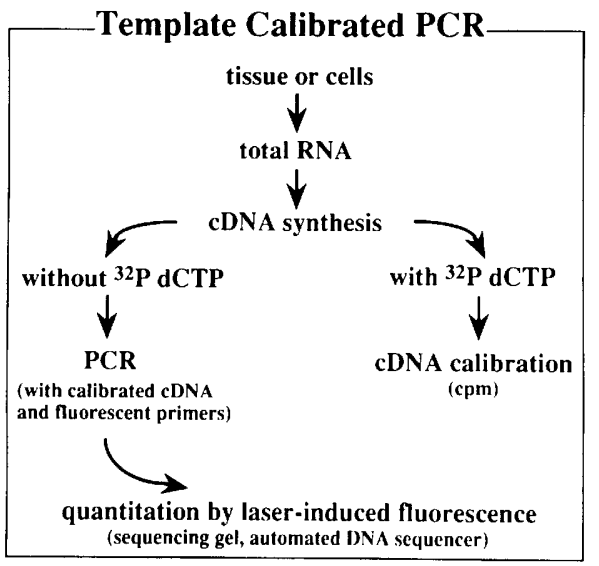

FIGURE 1 Flow diagram of template-calibrated RT-PCR.

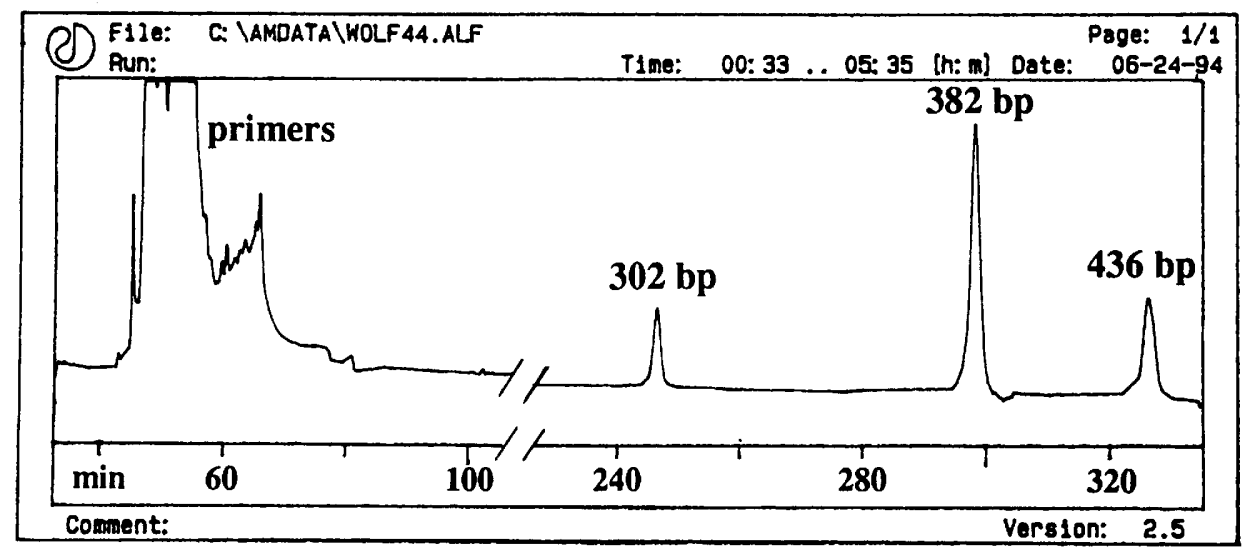

FIGURE 2 Detection and quantitation of fluorescence-labeled PCR products on a DNA sequencer. One of 40 lanes run in parallel is shown, with fluorescence peaks at min 245 ( $\beta$-glucuronidase, $302 \mathrm{bp}$ ), min 294 (internal standard, $382 \mathrm{bp}$ ), and min 333 (islet cell antigen p69, $436 \mathrm{bp}$ ). Peaks were analyzed using the FragmentManager software program.

were synthesized on a Gene Assembler Plus (Pharmacia) and fluorescein-labeled using fluorescein amidite (FluorePrime, Pharmacia). Amplification was performed in a Twin Block PCR system (Ericomp Inc., San Diego, CA): 4 min at $94^{\circ} \mathrm{C} ; 30 \mathrm{sec}$ at $55^{\circ} \mathrm{C}, 60 \mathrm{sec}$ at $72^{\circ} \mathrm{C}$, and $30 \mathrm{sec}$ at $94^{\circ} \mathrm{C}$, for 28 cycles; $30 \mathrm{sec}$ at $55^{\circ} \mathrm{C}$; 5 min at $72^{\circ} \mathrm{C}$. A 302-bp $\beta$-glucuronidase PCR product was generated spanning two introns. Specificity was confirmed by Southern blotting and hybridization with an internal oligonucleotide probe, $\beta$-Glu-P ( 5 '-GATAATTGGCTTCTGGTACAT-3'). Positive displacement pipettes with plugged tips were used throughout all procedures, and reagent blanks were interspersed in each reaction series as negative controls. To account for stochastic variability in PCR amplification, all reactions were performed in triplicate and samples to be compared were amplified in parallel.

\section{PCR Product Quantitation}

Fluorescence-labeled PCR products were analyzed on an automated DNA sequencer (A.L.F., Pharmacia) measuring laser-induced fluorescence (Fig. 2). Up to 40 samples, each containing one or several different PCR products (equivalent to $0.01-10 \mu \mathrm{l}$ of a $50 \mu \mathrm{l}$ PCR reaction) were denatured at $94^{\circ} \mathrm{C}$ and separated on a $6 \%$ polyacrylamide $/ 7 \mathrm{M}$ urea sequencing gel. Each lane received a standard amount of a fluoresceinated PCR product (382 bp in size) for calibration. Fluorescence signals were analyzed with FragmentManager software (Pharmacia).
The area under the curve of each peak was expressed in relative fluorescence units (RFU). Values represent the mean of three parallel PCR amplifications. The intra-assay (lane-to-lane) coefficient of variation for the quantitation of identical samples averaged 5.33\%.

\section{RESULTS \\ CDNA Synthesis and Calibration}

Denaturing gel electrophoresis and autoradiography, both not part of the routine procedure, confirmed the integrity, size distribution, and equal quantity of cDNA template used for PCR (Fig. 3). Extrapolation of the proportions of labeled $(0.167 \%)$ and unlabeled dCTP, the specific activity ( $-3000 \mathrm{Ci} / \mathrm{mmole})$, and the amount of label incorporated allowed the calculation of the absolute amount of cDNA generated from $3 \mu \mathrm{g}$ of reference RNA (81.6 $\mathrm{ng} / 40 \mu \mathrm{l}$ of reaction, equivalent to $2.72 \%$ of RNA input). To ensure that unincorporated $\left[\alpha{ }^{32} \mathrm{P}\right] \mathrm{dCTP}$ did not contribute to scintillation counts used for cDNA calibration, $\mathrm{RT}^{+}$and $\mathrm{RT}^{-}$ reaction samples were analyzed (Table 1). After spin column purification, only background counts were detectable in the absence of RT ( $\left.\mathrm{RT}^{-}\right)$, indicating that free nucleotides were removed with high efficiency $>98 \%$.

To determine the reliability of the RT procedure, six reactions with reference RNA were carried out in parallel yielding cDNA with a coefficient of variation of $12.9 \%$, that is, close to the specifications of micropipettors. It was therefore possible to restrict the use of small amounts 


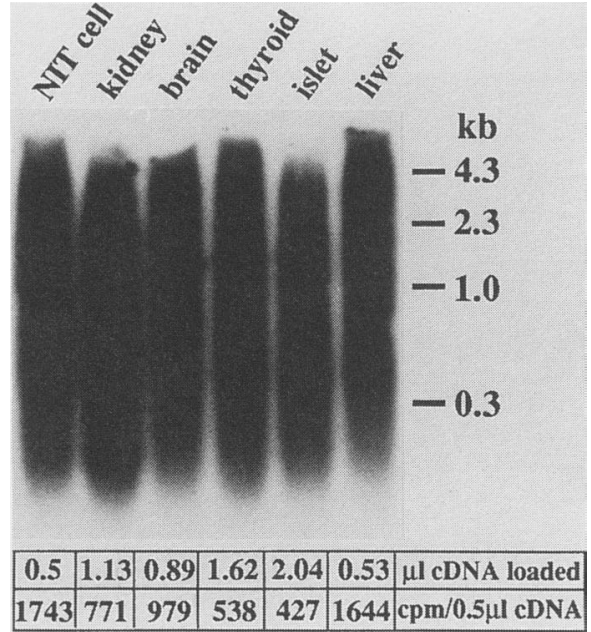

FIGURE 3 Autoradiograph of calibrated cDNA. $\left[\alpha-{ }^{32}\right.$ P]dCTP-Labeled cDNA from various rat tissues was size-fractionated by electrophoresis through an alkaline agarose gel (1\%), blotted onto a nylon membrane, and autoradiographed. Because of varying concentrations in cDNA stocks (inset bottom row), different volumes $(0.5-2.04 \mu \mathrm{l}$, inset top row) were loaded per lane, each containing identical quantities of cDNA (equivalent to 1743 cpm). Apparently, there is an even distribution in cDNA size and quantity between all samples, confirming the validity of cDNA calibration.

of isotope to a diagnostic cDNA reaction only while subsequent amplification and analysis were done with nonradioactive CDNA generated in a parallel reaction.

\section{Linearity of Fluorescence Signal}

Analyzing different concentrations of an identical $\beta$-glucuronidase PCR product, the fluorescence signal (RFU) was a linear function ( $r=0.97)$ of the amount of PCR product loaded over the entire detection range (Fig. 4a). Because of software design with an upper peak cutoff at $\sim 20,000 \mathrm{RFU}$, the absolute signal range is currently limited to two log steps. Loading varying dilutions equivalent to $0.01-10 \mu l$ of PCR product extended the actual detection range to five orders of magnitude.

\section{Exponential Phase of PCR Amplification}

The relationship between the numbers of amplification cycles and the amount of final PCR product was analyzed for the $\beta$-glucuronidase primer pair with a sample high in target gene expression using the equation $N=N_{\mathrm{o}}(1+E)^{\mathrm{n}}$, where $N=$ the number of amplified molecules, $N_{\mathrm{o}}=$ the initial number of molecules, $E=$ the amplification efficiency, and $\mathrm{n}=$ the cycle number. Rat kidney cDNA $(0.5 \mu \mathrm{l})$ was amplified in a 50- $\mu$ l PCR reaction, and aliquots were taken after various cycle numbers and analyzed by laser-induced fluorescence. There was an exponential increase $\left(1.9^{n}\right)$ of PCR product between cycles 23 and $29(E=0.9)$, with the amplification efficiency falling below $80 \%(E<0.8)$ after 32 cycles as the plateau phase was approached (Fig. $4 \mathrm{~b}$ ). PCR kinetics were confirmed by Southern blotting, oligonucleotide probing, and autoradiography (data not shown). Fluorescence analysis was 10 times more sensitive in detecting small amounts of PCR product. In conclusion, PCR quantitation is carried out in the desired exponential phase of amplification.

\section{PCR Product vs. Template Input}

Standard cDNA ( $2 \mathrm{ng} / \mu \mathrm{l}$, equivalent to $3487 \mathrm{cpm}$ ) was serially diluted and PCRamplified at 29 cycles in triplicate (Fig. $4 c$ ). We observed a linear increase of fluorescence signal with template input over a range from $6.4 \mathrm{pg}$ to $2.04 \mathrm{ng}$ of cDNA per $50 \mu \mathrm{l}$ of PCR reaction (equivalent to $0.24-75 \mathrm{ng}$ of total RNA). At larger cDNA inputs (e.g., $6.44 \mathrm{ng}$ of cDNA template per $50 \mu \mathrm{l}$ of reaction), PCR efficiency declined and the amount of product generated leveled off. The lower limit of linear detection was $\sim 5 \mathrm{pg}$ of cDNA per $50 \mu \mathrm{l}$ of reaction (equivalent to $0.2 \mathrm{ng}$ of total RNA), implying that gene expression of as little as 10-30 cells can be studied successfully in a quantitative fashion. The detection sys- tem is not limiting this sensitivity, as only one-fifth of the reaction volume (equivalent to two to six cells) was loaded and analyzed per lane.

\section{Variation of PCR Amplification}

To account for stochastic variation of PCR efficiency, all samples were PCR amplified in triplicate. Because the coefficient of variation (CV) for laser quantitation was low $(5.33 \%$, see Materials and Methods), we routinely pooled these three samples to reduce workload. Ten identical samples were analyzed in that manner (i.e., $10 \times 3$ PCR reactions), with a resulting $\mathrm{CV}$ for PCR amplification of $10.6 \%$ on a standard PCR block.

\section{Gene Expression Pattern of $\beta$-glucuronidase}

$\beta$-Glucuronidase, a lysosomal enzyme, is constitutively expressed at very low and supposedly equal transcription levels in many tissues. ${ }^{(8)}$ Using this "housekeeping" gene as an example, we tested our experimental strategy and drew a map of differential gene expression for this protein in various rat tissues (Fig. 5). As can be seen, expression levels are similar in most tissues except in liver, where it is abundant. However, up to threefold differences between different tissues are apparent.

\section{DISCUSSION}

Laser-induced fluorescence analysis (LIF) of PCR-amplified DNA fragments after size fractionation through capillary gel $^{(9)}$ or polyacrylamide gel ${ }^{(10)}$ electrophoresis is a fast, reliable, and environ-

TABLE 1 High Efficiency of cDNA Purification

\begin{tabular}{|c|c|c|}
\hline cDNA sample & $\begin{array}{l}\text { Counts per minute/ } \\
40-\mu l \text { reaction }\end{array}$ & $\begin{array}{l}\text { Counts per minute } \\
\text { (\% of total) }\end{array}$ \\
\hline Before column $\left(\mathrm{RT}^{+}\right.$or $\left.\mathrm{RT}^{-}\right)$ & $1,962,400$ & 100 \\
\hline After column $\left(\mathrm{RT}^{+}\right)$ & 139,480 & 7.10 \\
\hline After column ( $\left.\mathrm{RT}^{-}\right)$ & 77 & 0.0039 \\
\hline No sample & 21 & N.A. \\
\hline
\end{tabular}

Two cDNA synthesis reactions $(40 \mu \mathrm{l})$ with $0.5 \mu \mathrm{g}$ of NIT cell RNA and $1 \mu \mathrm{l}$ of $\left[\alpha{ }^{32} \mathrm{P}\right] \mathrm{dCTP}$ were performed in parallel, either in the presence $\left(\mathrm{RT}^{+}\right)$or absence $\left(\mathrm{RT}^{-}\right)$of 200 units of Mo-MLV reverse transcriptase. Aliquots were analyzed by fluid scintillation counting before and after purification on Sephacryl spin columns (MicroSpin S-200HR, Pharmacia); counts are expressed per $40-\mu \mathrm{l}$ reaction. Results indicate that in purified samples $>99 \%$ of radioactivity measured is incorporated into cDNA. 

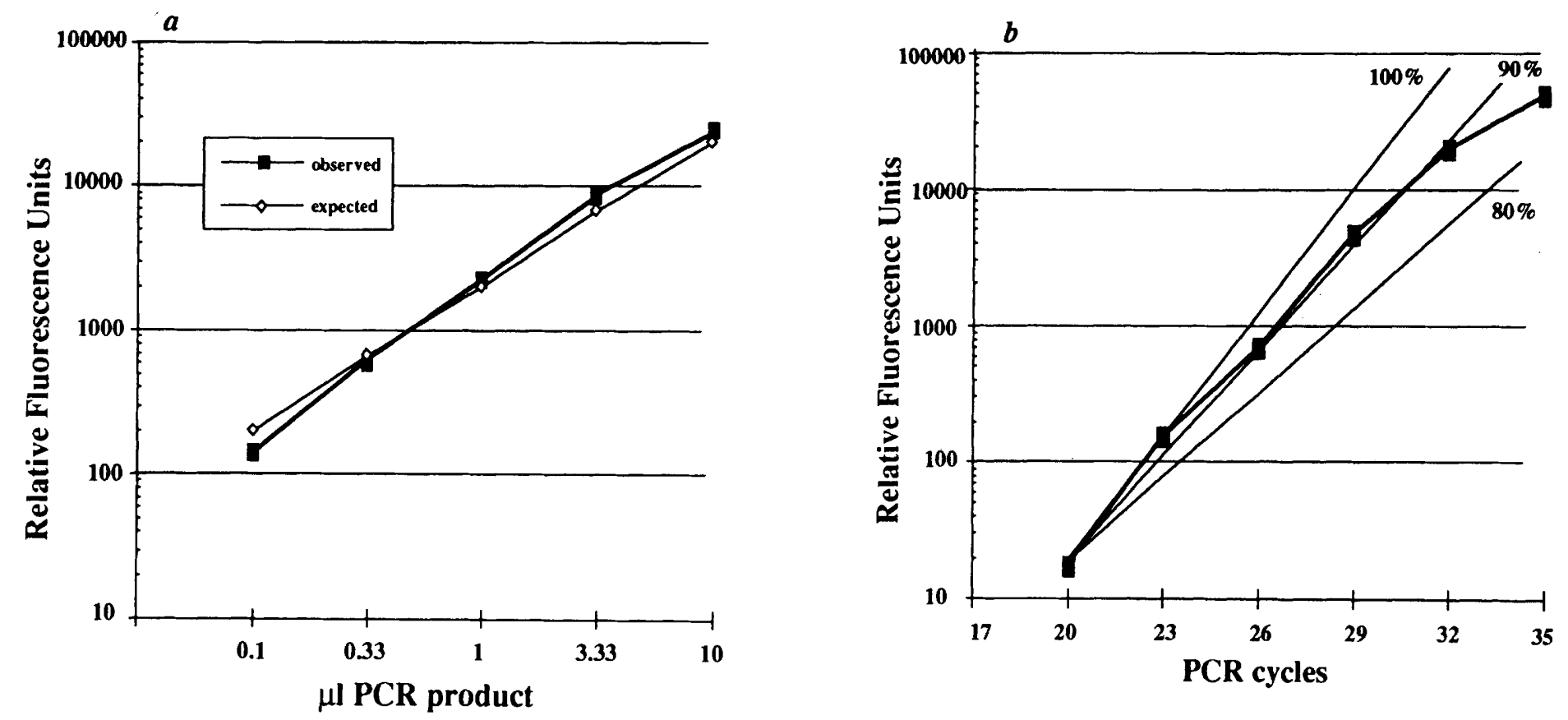

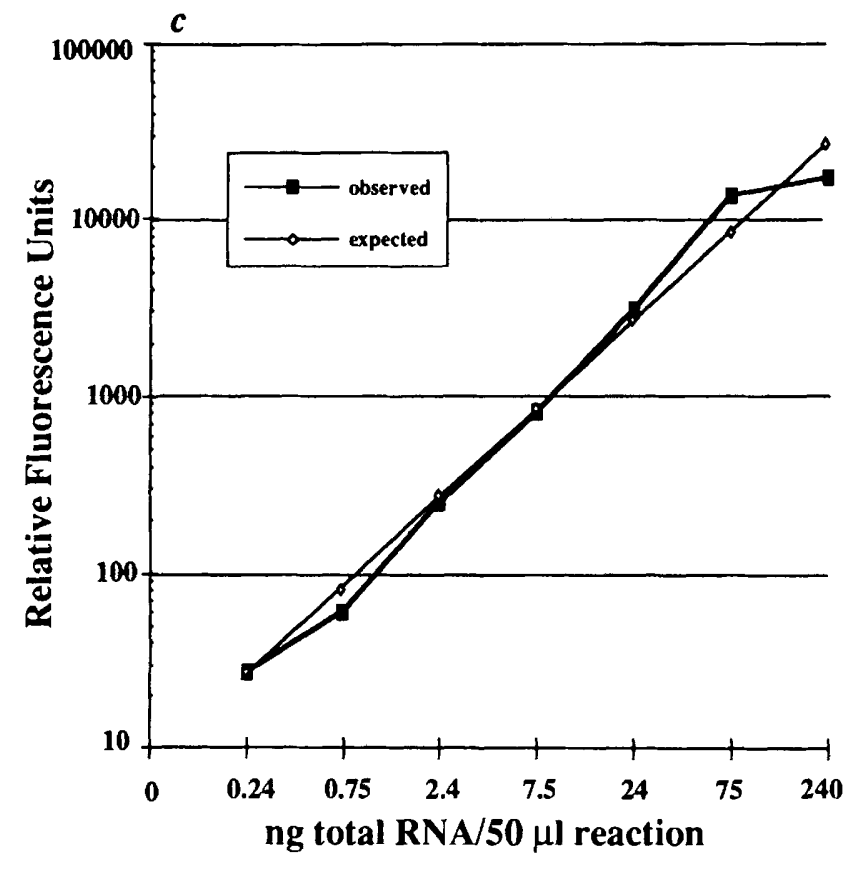

FIGURE 4 (a) Linearity of fluorescence signal. Identical $\beta$-glucuronidase PCR products $(0.1-10 \mu \mathrm{l})$ were loaded on the DNA sequencer and quantitated as described in Materials and Methods. Over the entire detection range, there is a strictly linear relationship between the quantity of PCR product and the fluorescence signal (RFU). (b) Exponential phase of PCR amplification. Rat kidney cDNA $(0.5 \mu \mathrm{l})$ was PCR amplified using $\beta$-glucuronidase primers as described in Materials and Methods. Aliquots were taken after various cycle numbers ( $n=17-35$ ), and the PCR product was quantitated (see Materials and Methods). No product was detectable after 17 cycles. There is an exponential increment of PCR product between cycles 20 and 29 with an amplification efficiency $\geqslant 90 \%$. Hypothetical growth curves for the PCR product (calculated for an amplification efficiency of $100 \%, 90 \%$, or $80 \%$, respectively), starting from the actual quantity of molecules at 20 cycles, are included for illustration (straight lines). (c) Linearity of PCR product vs. template input. After serial dilution, $3.16 \mathrm{nl}-$ $3.16 \mu \mathrm{l}$ of NIT cell $\mathrm{cDNA}(2 \mathrm{ng} / \mu \mathrm{l})$ equivalent to $0.24-240 \mathrm{ng}$ of total RNA was amplified by PCR over 29 cycles using $\beta$-glucuronidase primers (see Materials and Methods). The PCR reaction (0.01-10 $\mu \mathrm{l}$ ) was then analyzed by laser-induced fluorescence. There is a linear correlation between template input and fluorescence signal over a range of $2 \frac{1 / 2}{2}$ orders of magnitude. mentally friendly alternative to conventional, isotope-based PCR quantitation techniques. We used LIF here in an automated DNA sequencer able to analyze up to 40 samples simultaneously, each containing several fluorescence-labeled PCR products. High-resolution sequencing gel and addition of a calibration and size standard facilitated the identification and linear quantitation of each PCR product peak with high precision and reproducibility over a $10^{5}$-fold concentration range. The lower limit of quantita- tion (equivalent to $50 \mathrm{pg}$ of total RNA) is not a function of the detection system, and minimizing assay volumes will probably allow analysis of smaller quantities, for example, clinical biopsies.

Stochastic variation of amplification, thought to arise from random variation in amplification efficiency during the first PCR cycles, is an inherent concern in any PCR quantitation. We amplified each sample in triplicate, and for practicality, pooled aliquots prior to quantitation with a resulting average coefficient of variation of $10.6 \%$ on a standard PCR block.

To control for template input, cDNA was calibrated after synthesis and purification. Input variation resulting from different reverse transcription efficiencies or RNA quantity or quality was thus minimized. In addition, neither degradation nor contamination with genomic DNA is accessible to spectrophotometric analysis in standard procedures. Template standardization has been reported for random-primed cDNA generated 


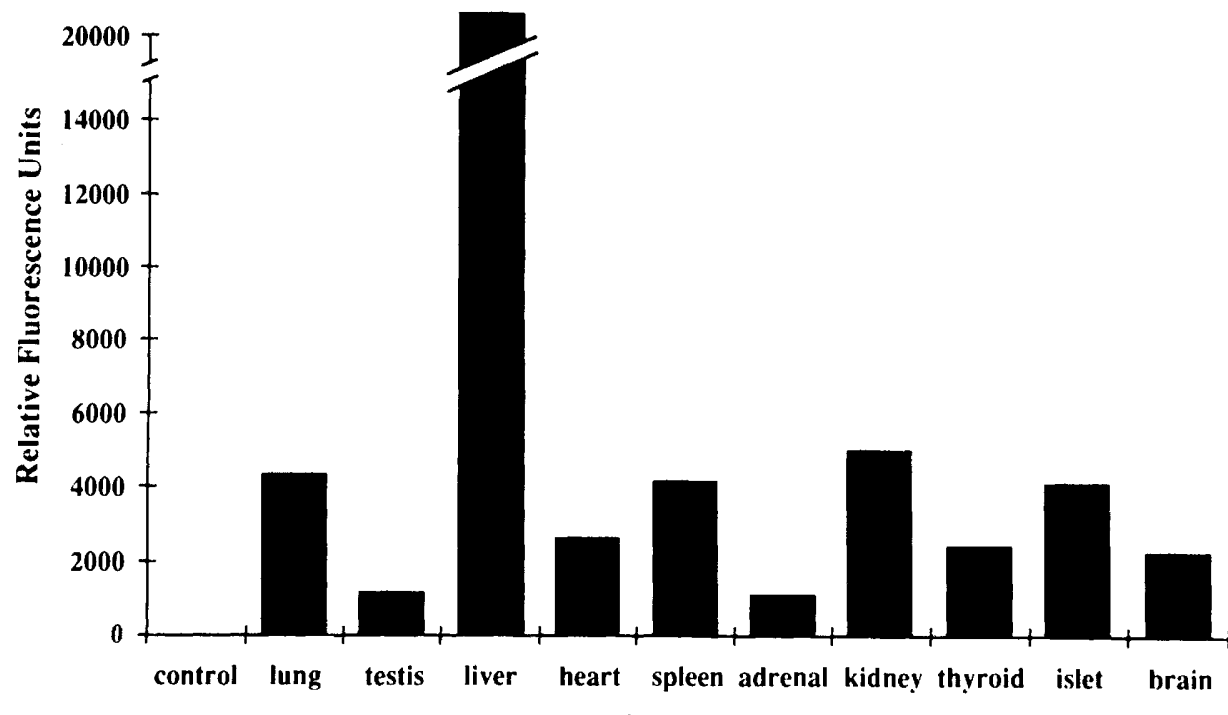

tissue

FIGURE 5 Gene expression pattern of $\beta$-glucuronidase. After calibration, equal amounts of cDNA from various rat tissues were PCR amplified with $\beta$-glucuronidase primers for 29 cycles (see Materials and Methods). No cDNA template was added to the reagent control. PCR products were quantitated by laser-induced fluorescence. Values are expressed in relative fluorescence units and represent two analyses of three PCR reactions. Coefficients of variation were $\leqslant 11 \%$.

from bulk RNA. ${ }^{(11)}$ By using oligo(dT) for RT priming, we synthesize cDNA from polyadenylated mRNA only but not from other RNA species (e.g., rRNA) that account for the majority of cellular RNA. Therefore, calibration is achieved with mRNA-derived cDNA that truly represents the pool of gene transcripts within a given cell. Equal amounts of this cDNA serve as one independent standard for subsequent PCR quantification. To avoid interference with contaminating genomic DNA as PCR template, primers used for RT-PCR were located on seperate exons.

We did not systematically compare our approach with strategies based on standardization of input RNA. However, we quantitated total RNA spectrophotometrically prior to reverse transcription and used $3 \mu \mathrm{g}$ for cDNA synthesis. Despite nominally "equal" amounts of total RNA, up to eightfold differences in oligo(dT)-primed cDNA were detectable. Figure 3 shows that these differences are real.

Housekeeping genes like actin, GAPDH, or $\beta$-glucuronidase are used frequently as internal standards in noncompetitive RT-PCR studies. ${ }^{(1)}$ Within one tissue or cell type, these genes provide practical controls for template input, unless expression of control and test transcripts are both affected by the reg- ulatory events to be studied. So far, no gene has been identified with truly even tissue distribution appropriate as gold standard for quantitative gene expression studies in different tissues or cell types. Our data here exemplify that $\beta$-glucuronidase shows expression levels within one order of magnitude (except for abundant expression in liver), but our cDNA calibration approach delineates significant differences from tissue to tissue.

We did not attempt to determine absolute levels of gene expression (e.g., transcript copies per cell or milligram of tissue), which would require rigorous control of absolute sample input, RNA isolation and transcription. However, the use of identical amounts of oligo(dT) primed CDNA as a reference point makes our approach especially suitable to compare gene transcription in different cells or tissues.

In small biological samples, RNA extraction and assessment is often impractical, and control of template input may therefore be impossible. The quantity of starting material is often unknown, prohibiting the use of exogenous RNA standards. ${ }^{(12)}$ cDNA calibration as outlined here can, however, be performed even in simplified transcription protocols ${ }^{(13)}$ without separate RNA isolation ("onetube $\mathrm{RT}^{\prime \prime}$ ). RT-PCR using cDNA calibra- tion and sensitive fluorescence detection may provide a useful tool to quantitate gene expression in small and unique tissue samples of unknown quantity, such as organ biopsies in clinical medicine.

\section{ACKNOWLEDGMENTS}

This work was supported by grants from the Medical Research Council of Canada and the Juvenile Diabetes Foundation International. W.K. is a fellow of the Deutsche Forschungsgemeinschaft, Ka 1046/1-1.

\section{REFERENCES}

1. Gause, W.C. and J. Adamovicz. 1994. The use of the PCR to quantitate gene expression. PCR Methods Applic. 3: S123-S135.

2. Ferre, F. 1993. Quantitative or semi-quantitative PCR: Reality versus myth. $P C R$ Methods Applic. 2: 1-9.

3. Gaedigk, R., A.M.V. Duncan, I. Miyazaki, B.H. Robinson, and H.-M. Dosch. 1994. ICA1 encoding p69, a protein linked to the development of type 1 diabetes mellitus, maps to chromosome $7 \mathrm{p} 22$. Cytogenet. Cell Genet. 66: 274-276.

4. Miyazaki, I., R. Gaedigk, M.F. Hui, R.K. Cheung, J. Morkowski, R.V. Rajotte, and H.-M. Dosch. 1994. Molecular cloning of human and rat p69, a candidate autoimmune target in Type I diabetes. Biochim. Biophys. Acta (in press).

5. Karges, W.J.P. and H.M. Dosch (in prep.)

6. Hamaguchi, K., H.R. Gaskins, and E.H. Leiter. 1991. NIT-1, a pancreatic $\beta$-cell line established from a transgenic NOD/Lt mouse. Diabetes 40: 842-849.

7. Chomczynski, P. and N. Sacchi. 1987. Single-step method of RNA isolation by acid guanidinium thiocyanate-phenol-chloroform extraction. Anal. Biochem. 162: 156159.

8. Nishimura, Y., M.G. Rosenfeld, G. Kreibich, U. Gubler, D.D. Sabatini, M. Adesnik, and R. Andy. 1986. Nucleotide sequence of rat preputial gland $\beta$-glucuronidase cDNA and in vitro insertion of its encoded polypeptide into microsomal membranes. Proc. Natl. Acad. Sci. 83: 7292-7296.

9. Lu, W., D.S. Han, J. Yuan, and J.-M. Andrieu. 1994. Multi-target PCR analysis by capillary electrophoresis and laser-induced fluorescence. Nature 368: 269271.

10. Porcher, C., M.-C. Malinge, C. Picat, and B. Grandchamp. 1992. A simplified method for determination of specific DNA or RNA copy number using quantitative PCR and an automatic DNA sequencer. BioTechniques 13: 106-113.

11. Kolls, J., P. Deininger, J.C. Cohen, and J. 
Larson. 1993. cDNA equalization for reverse transcription-polymerase chain reaction quantitation. Anal. Biochem. 208: 264-269.

12. Puntschart, A., K. Jostarndt, H. Hoppeler, and R. Billeter. 1994. An efficient polymerase chain reaction approach for the quantitation of multiple RNAs in human tissue samples. PCR Methods Applic. 3: 232-238.

13. Higuchi, R. 1989. Simple and rapid preparation of samples for PCR. In PCR technology: Principles and applications for DNA amplification (ed. H.A. Ehrlich), pp. 3138. Stockton Press, New York.

Received September 12, 1994; accepted in revised form October 25, 1994. 


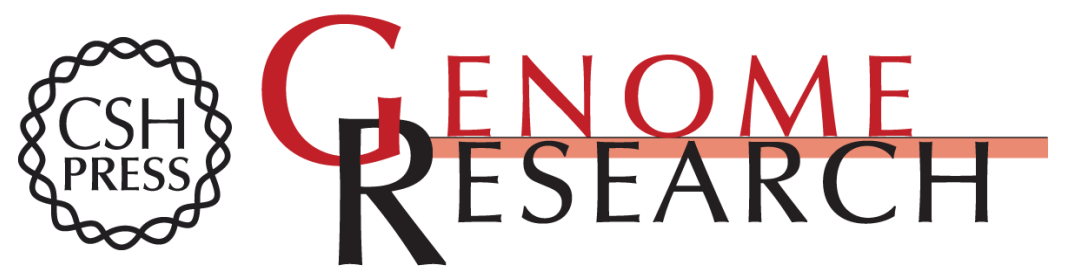

\section{Quantitative analysis of gene expression in different tissues by template-calibrated RT-PCR and laser-induced fluorescence.}

W J Karges, R Gaedigk and H M Dosch

Genome Res. 1994 4: 154-159

References This article cites 10 articles, 2 of which can be accessed free at: http://genome.cshlp.org/content/4/3/154.full.html\#ref-list-1

License

Email Alerting

Receive free email alerts when new articles cite this article - sign up in the box at the Service top right corner of the article or click here.

\section{Affordable, Accurate Sequencing.}

To subscribe to Genome Research go to: https://genome.cshlp.org/subscriptions 